University of Nebraska - Lincoln

DigitalCommons@University of Nebraska - Lincoln

Agronomy \& Horticulture -- Faculty Publications

Agronomy and Horticulture Department

$7-2020$

\title{
Soil-nitrogen, potentially mineralizable-nitrogen, and field condition information marginally improves corn nitrogen management
}

\author{
Jason Clark \\ South Dakota State University, jason.d.clark@sdstate.edu \\ Fabián G. Fernández \\ University of Minnesota - Twin Cities, fabiangf@umn.edu \\ Kristen S. Veum \\ USDA, Agricultural Research Service, kristen.veum@usda.gov \\ James J. Camberato \\ Purdue University, jcambera@purdue.edu \\ Paul R. Carter \\ Clive, IA \\ Follow this and additional works at: https://digitalcommons.unl.edu/agronomyfacpub \\ see rart of the fagriculdural Science forditional authors \\ Commons, Botany Commons, Horticulture Commons, Other Plant Sciences Commons, and the Plant \\ Biology Commons
}

Clark, Jason; Fernández, Fabián G.; Veum, Kristen S.; Camberato, James J.; Carter, Paul R.; Ferguson, Richard; Franzen, David W.; Kaiser, Daniel E.; Kitchen, Newell R.; Laboski, Carrie A.M.; Nafziger, Emerson; Rosen, Carl J.; Sawyer, John E.; and Shanahan, John F., "Soil-nitrogen, potentially mineralizable-nitrogen, and field condition information marginally improves corn nitrogen management" (2020). Agronomy \& Horticulture -- Faculty Publications. 1451.

https://digitalcommons.unl.edu/agronomyfacpub/1451

This Article is brought to you for free and open access by the Agronomy and Horticulture Department at DigitalCommons@University of Nebraska - Lincoln. It has been accepted for inclusion in Agronomy \& Horticulture -Faculty Publications by an authorized administrator of DigitalCommons@University of Nebraska - Lincoln. 


\section{Authors}

Jason Clark, Fabián G. Fernández, Kristen S. Veum, James J. Camberato, Paul R. Carter, Richard

Ferguson, David W. Franzen, Daniel E. Kaiser, Newell R. Kitchen, Carrie A.M. Laboski, Emerson Nafziger,

Carl J. Rosen, John E. Sawyer, and John F. Shanahan 
Soil Fertility \& Crop Nutrition

\title{
Soil-nitrogen, potentially mineralizable-nitrogen, and field condition information marginally improves corn nitrogen management
}

\author{
Jason D. Clark ${ }^{1}$ (1) ～| Fabián G. Fernández ${ }^{2} \quad$ Kristen S. Veum ${ }^{3}$ (i) | \\ James J. Camberato ${ }^{4}$ (D) | Paul R. Carter ${ }^{5} \quad$ | Richard B. Ferguson ${ }^{7}$ | \\ David W. Franzen ${ }^{6}$ (D) ～Daniel E. Kaiser ${ }^{2}$ (D) | Newell R. Kitchen ${ }^{3}$ (D) | \\ Carrie A. M. Laboski ${ }^{8} \quad$ Emerson D. Nafziger ${ }^{9}$ (D) | Carl J. Rosen ${ }^{2}$ | \\ John E. Sawyer ${ }^{10} \quad$ John F. Shanahan ${ }^{11}$
}

${ }^{1}$ South Dakota State Univ., 1148 Medary Ave., Brookings, SD 57007

${ }^{2}$ Univ. of Minnesota, 1991 Upper Buford Circle, St. Paul, MN 55108

${ }^{3}$ USDA-ARS Cropping Systems and Water Quality Research Unit, Columbia, MO 65211

${ }^{4}$ Purdue Univ., 915 W. State St., West Lafayette, IN 47907

${ }^{5} 13801$ Summit Drive, Clive, IA 50325

${ }^{6}$ North Dakota State Univ., PO Box 6050, Fargo, ND 58108

${ }^{7}$ Univ. of Nebraska, Keim 367, Lincoln, NE 68583

${ }^{8}$ Univ. of Wisconsin-Madison, 1525 Observatory Dr., Madison, WI 53706

${ }^{9}$ Univ. of Illinois, 1102 S. Goodwin, Urbana, IL 61801

${ }^{10}$ Iowa State Univ., 3208 Agronomy Hall, 716 Farm House Lane, Ames, IA 50011

${ }^{11}$ Soil Health Institute, 6807 Ridge Rd, Lincoln, NE 68512

\section{Correspondence}

Jason D. Clark, South Dakota State Univ., 1148 Medary Ave., Brookings, SD 57007.

Email: Jason.D.Clark@sdstate.edu

Funding information DuPont Pioneer

\begin{abstract}
Anaerobic potentially mineralizable nitrogen (PMN) combined with preplant nitrate test (PPNT) or pre-sidedress nitrate test (PSNT) may improve corn (Zea mays L.) N management. Forty-nine corn $\mathrm{N}$ response studies were conducted across the U.S. Midwest to evaluate the capacity of PPNT and PSNT to predict grain yield, $\mathrm{N}$ uptake, and economic optimal $\mathrm{N}$ rate (EONR) when adjusted by soil sampling depth, soil texture, temperature, $\mathrm{PMN}$, and initial $\mathrm{NH}_{4}-\mathrm{N}$ from PMN analysis. Pre-plant soil samples were obtained for PPNT (0- to 30-, 30- to 60-, 60- to 90-cm depths) and PMN (0- to 30-cm depth) before corn planting and $\mathrm{N}$ fertilization. In-season soil samples were obtained at the V5 corn development stage for PSNT (0- to 30-, 30- to $60-\mathrm{cm}$ depths) at $0 \mathrm{~kg} \mathrm{~N} \mathrm{ha}^{-1}$ at-planting rate and for PMN when 0 and $180 \mathrm{~kg} \mathrm{~N} \mathrm{ha}^{-1}$ was applied at planting. Grain yield, $\mathrm{N}$ uptake, and EONR were best predicted when separating soils by texture or sites by annual growing degree-days and including $\mathrm{PMN}$ and initial $\mathrm{NH}_{4}-\mathrm{N}$ with either $\mathrm{NO}_{3}-$ $\mathrm{N}$ test. Using PSNT (mean $R^{2}=.30$ )-instead of PPNT (mean $R^{2}=.19$ )-based models normally increased predictability of corn agronomic variables by a mean of $11 \%$. Including PMN and initial $\mathrm{NH}_{4}-\mathrm{N}$ with PPNT or PSNT only marginally improved predictability of grain yield, $\mathrm{N}$ uptake, and EONR $\left(R^{2}\right.$ increase $\leq .33$; mean $R^{2}=.35$ ). Therefore, including PMN with PPNT or PSNT is not suggested as a tool to improve $\mathrm{N}$ fertilizer management in the U.S. Midwest.
\end{abstract}

Abbreviations: EONR, economic optimal $\mathrm{N}$ rate; GDD, growing degree-day; $\mathrm{PMN}$, anaerobic potentially mineralizable $\mathrm{N} ; \mathrm{PP}_{0 \mathrm{~N}}$, pre-plant soil sampling where $0 \mathrm{~kg} \mathrm{~N} \mathrm{ha}^{-1}$ was applied at planting; PPNT, pre-plant nitrate test; PSNT, pre-sidedress nitrate test; $\mathrm{V} 5_{\mathrm{ON}}$, V5 


\section{1 | INTRODUCTION}

Estimation of $\mathrm{N}$ mineralization is critical for improving $\mathrm{N}$ fertilizer guidelines as mineralization contributes $20-100 \%$ of the total plant $\mathrm{N}$ needs depending on factors including soil, previous crop, weather, and $\mathrm{N}$ management (Broadbent \& Hauck, 1984; Khan, Mulvaney, \& Hoeft, 2001; Morris et al., 2018; Roberts, Ross, Norman, Slaton, \& Wilson, 2011; Ros, Temminghoff, \& Hoffland, 2011; Yost, Coulter, Russelle, Sheaffer, \& Kaiser, 2012). The interaction of these and other biotic and abiotic factors makes mineralization difficult to predict. Accurately estimating mineralization is important as it reduces the potential negative economic and environmental effects of over- or under-applications of $\mathrm{N}$ fertilizer.

The pre-plant nitrate test (PPNT) and pre-sidedress nitrate test (PSNT) have strong relationships with corn grain yield, $\mathrm{N}$ uptake, and economic optimal $\mathrm{N}$ rate (EONR), and have been used to reduce the potential for over- and under- applying $\mathrm{N}$ fertilizer (Andraski \& Bundy, 2002; Barbieri, Echeverría, \& Saínz Rozas, 2008; Bundy \& Andraski, 1995; Bundy, Walters, \& Olness, 1999; Kuo, Sainju, \& Jellum, 1996; Magdoff, Ross, \& Amadon, 1984; Nyiraneza et al., 2010). For the PPNT, the soil profile is sampled in $30-\mathrm{cm}$ increments up to $90 \mathrm{~cm}$ (depending on the crop and soil type) for $\mathrm{NO}_{3}-\mathrm{N}$ concentration before planting and $\mathrm{N}$ fertilization. The PPNT accounts for the $\mathrm{NO}_{3}-\mathrm{N}$ carried over from the previous season and the amount mineralized to that point in time. For the PSNT, the soil profile is sampled in $30-\mathrm{cm}$ increments up to 60 -cm deep for $\mathrm{NO}_{3}-\mathrm{N}$ concentration near the V6 corn development stage. Delaying soil $\mathrm{NO}_{3}-\mathrm{N}$ sampling from preplant to near V6 allows the soil test to account for more of the $\mathrm{N}$ mineralization potential of the soil by measuring the net amount of $\mathrm{N}$ after gain (mineralization) and loss (leaching, denitrification, and immobilization) processes that take place and before the rapid corn $\mathrm{N}$ uptake period begins (Abendroth, Elmore, Boyer, \& Marlay, 2011; Magdoff et al., 1984).

Although the PPNT and PSNT alone improved N management of corn in the U.S. Midwestern Corn Belt and Canadian British Columbia, $\mathrm{N}$ fertilization was still recommended when it was not needed $23-39 \%$ of the time (Brouder \& Mengel, 2003; Bundy et al., 1999; Zebarth, Younie, Paul, \& Bittman, 2002). The failure to correctly predict $\mathrm{N}$ needs by these soil tests may be the result of large amounts of $\mathrm{NO}_{3}-\mathrm{N}$ present below the $0-$ to $30-\mathrm{cm}$ sampling depth that is most used for the PPNT and PSNT.

soil sampling where $0 \mathrm{~kg} \mathrm{~N} \mathrm{ha}^{-1}$ was applied at planting; $\mathrm{V}_{180 \mathrm{~N}}$, V5 soil sampling where $180 \mathrm{~kg} \mathrm{~N} \mathrm{ha}^{-1}$ was applied at planting.

(c) 2020 The Authors. Agronomy Journal @ 2020 American Society of Agronomy
Other reasons the PPNT and PSNT fail to correctly predict $\mathrm{N}$ needs may be the result of greater $\mathrm{N}$ leaching potential in coarse-textured soils, years with lower than normal spring temperatures that limit mineralization before samples are taken, and years when greater rainfall reduces estimates of mineralizable $\mathrm{N}$ because of $\mathrm{NO}_{3}-\mathrm{N}$ loss before and after soil sampling (Andraski \& Bundy, 2002; Magdoff, 1991; Yost, Russelle, \& Coulter, 2013). Including a soil test that correctly estimates the amount of $\mathrm{N}$ that can be mineralized in the soil profile throughout the growing season, beyond the soil $\mathrm{NO}_{3}-\mathrm{N}$ measured with the PPNT and PSNT, could improve our ability to make $\mathrm{N}$ management decisions.

The anaerobic potentially mineralizable $\mathrm{N}$ test (PMN) estimates $\mathrm{N}$ mineralization potential and has related well $\left(R^{2}=.33-.74\right)$ to EONR, relative yield, and $\mathrm{N}$ uptake of corn (Nyiraneza, N'Dayegamiye, Chantigny, \& Laverdière, 2009; Williams, Crozier, White, Sripada, \& Crouse, 2007). In Argentina, using the PMN test to separate soils into low and high mineralizable $\mathrm{N}$ categories improved relative yield predictability by the PSNT for the low PMN group (Sainz Rozas, Calvino, Echeverria, Barbieri, \& Redolatti, 2008). In addition, the inclusion of PMN to PPNT and PSNT using multiple regression improved $\mathrm{N}$ diagnostics 5-42\% in both wheat (Triticum aestivum L.) and corn (Zea mays L.) in Argentina (Orcellet, Reussi Calvo, Sainz Rozas, Wyngaard, \& Echeverría, 2017; Reussi Calvo, Sainz Rozas, Echeverría, \& Berardo, 2013). However, to date, there is a lack of systematic studies across the varying soil and weather conditions of the U.S. Midwest that investigate the potential utility of PMN as a variable with PPNT or PSNT to improve corn grain yield, $\mathrm{N}$ uptake, or EONR predictions.

To improve the potential use of the PMN test in predicting corn grain yield, $\mathrm{N}$ uptake, and EONR, it is important to explore additional considerations because sample timing and $\mathrm{N}$ fertilization can influence PMN (Clark et al., 2020; Culman, Snapp, Green, \& Gentry, 2013; Mahal, Castellano, $\&$ Miguez, 2018). For example, PMN from soil sampled before planting in medium- and fine-textured soils best predicted corn EONR, whereas PMN from near the V5 corn stage best predicted EONR in coarse-textured soils (Clark et al., 2019a). Additionally, $\mathrm{N}$ fertilizer application before soil sampling resulted in inconsistent outcomes from mineralization tests (Fernández, Fabrizzi, \& Naeve, 2017; Kuzyakova, Turyabahika, \& Stahr, 2006; Ma, Dwyer, \& Gregorich, 1999). Specifically, N fertilization at planting increased PMN from in-season soil samples in soils with organic carbon (C) $>21 \mathrm{~g} \mathrm{~kg}^{-1}$ and clay content $<9.5 \%$, and reduced PMN under the opposite conditions (Clark et al., 2019b). Therefore, the objective of this study was to evaluate PPNT and PSNT as predictors of grain yield, $\mathrm{N}$ uptake, 
and EONR when adjusted by soil sampling depth, soil texture, temperature, and $\mathrm{PMN}$ and initial $\mathrm{NH}_{4}-\mathrm{N}$ from PMN analysis from different sampling times and $\mathrm{N}$ fertilization rates.

\section{2 | MATERIALS AND METHODS}

\subsection{Experimental design}

Research was conducted at two to three experimental sites each year from 2014 to 2016 representing higher- and lower-yielding environments in each of eight U.S. Midwestern states (Illinois, Indiana, Iowa, Minnesota, Missouri, Nebraska, North Dakota, and Wisconsin) for a total of 49 site-years. Corn was grown each year with the previous crop being soybean [Glycine $\max$ (L.) Merr.] in 43 siteyears, corn in five site-years, and sunflower (Helianthus annus) in one site-year. Research sites had no recent $(>5 \mathrm{yr})$ manure application history and varied widely in their soil properties and weather conditions (Table 1 Supplemental Table S1). Nine $\mathrm{N}$ fertilizer treatments with four replications were used in a randomized complete block design at each site. Two $\mathrm{N}$ fertilizer treatments consisted of a control of $0 \mathrm{~kg} \mathrm{~N} \mathrm{ha}^{-1}$ and a single at-planting $\mathrm{N}$ application of $180 \mathrm{~kg} \mathrm{~N} \mathrm{ha}^{-1}$. Seven treatments consisted of a split application with $45 \mathrm{~kg} \mathrm{~N} \mathrm{ha}^{-1}$ applied at planting and 45$315 \mathrm{~kg} \mathrm{~N} \mathrm{ha}^{-1}$ (in $45 \mathrm{~kg} \mathrm{~N} \mathrm{ha}^{-1}$ increments) applied as a sidedress application. The sidedress application was completed at the V8-V10 corn development stage (Abendroth et al., 2011), except for North Dakota in 2015 and 2016 that occurred between V5 and V8. The zero control and seven split-N applications were used to create a complete corn grain yield response curve to split-N applications. The single at-planting $180 \mathrm{~kg} \mathrm{~N} \mathrm{ha}^{-1}$ treatment was only used to obtain soil samples at V5 to estimate the effect of $\mathrm{N}$ fertilization on the estimate of potentially mineralizable $\mathrm{N}$ used to improve prediction of the agronomic variables in this study. In all treatments, fertilizer was surface-applied using ammonium nitrate $\left(340 \mathrm{~g} \mathrm{~N} \mathrm{~kg}^{-1}\right)$. A detailed description of the research protocol, experimental sites, soil type information, and agronomic practices is provided in Kitchen et al. (2017).

\subsection{Soil sampling and analysis}

Before planting at each experimental site, 90 -cm-deep soil samples (3.8-4 $\mathrm{cm}$ i.d.) were collected and separated by horizons to measure soil texture, total organic $\mathrm{C}$, soil organic matter, and total $\mathrm{N}$ as described in Kitchen et al. (2017). Weighted averages of these measurements were calculated using the depth of each horizon within the top

\section{Core Ideas}

- Soil $\mathrm{NO}_{3}-\mathrm{N}$ from $\mathrm{V} 5$ corn compared to pre-plant improved grain yield, $\mathrm{N}$ uptake, and $\mathrm{N}$ requirement predictions.

- Soil $\mathrm{NO}_{3}-\mathrm{N}$ sample $>30 \mathrm{~cm}$ improved corn agronomic predictions only at the V5 corn stage.

- Partitioning soils by texture or air temperature marginally improved corn agronomic predictions.

- Combining soil $\mathrm{NO}_{3}-\mathrm{N}, \mathrm{NH}_{4}-\mathrm{N}$, and a mineralization estimate marginally improved corn agronomic predictions.

$30 \mathrm{~cm}$. Soil samples were obtained before planting and fertilization from each replication and at the V5 corn development stage from the 0 and $180 \mathrm{~kg} \mathrm{~N} \mathrm{ha}^{-1}$ at-planting $\mathrm{N}$ rate. Preplant samples were obtained using a 10-core (90-cm depth in 30-cm increments; $1.9-4.0 \mathrm{~cm}$ i.d.) composite soil sample and a six-core $(60-\mathrm{cm}$ depth in $30-\mathrm{cm}$ increments, $1.9 \mathrm{~cm}$ i.d.) composite soil sample at V5. Soil samples were dried $\left(\leq 32{ }^{\circ} \mathrm{C}\right)$ and then ground to pass through a 2-mm sieve. Soil $\mathrm{NO}_{3}-\mathrm{N}$ for the PPNT was extracted from all of the preplant soil samples and only the $0 \mathrm{~kg} \mathrm{~N} \mathrm{ha}^{-1}$ rate at V5 for the PSNT using $0.2 \mathrm{M} \mathrm{L}^{-1}$ $\mathrm{KCl}$ (Saha, Sonon, \& Biswas, 2018) and quantified using the cadmium reduction method (Gelderman \& Beegle, 2015) with a modified Technicon AutoAnalyzer (SEAL Analytical, Fareham, UK).

The PMN test was performed on a subset of the soil samples including the pre-plant soil samples where $0 \mathrm{~kg} \mathrm{~N} \mathrm{ha}^{-1}$ was applied at planting $\left(\mathrm{PP}_{0 \mathrm{~N}}\right)$ and the V5 soil samples where $0\left(\mathrm{~V}_{0 \mathrm{~N}}\right)$ and $180 \mathrm{~kg} \mathrm{~N} \mathrm{ha}^{-1}\left(\mathrm{~V}_{180 \mathrm{~N}}\right)$ was applied at-planting. Only the top $30 \mathrm{~cm}$ of these soils were analyzed for PMN in order to remain consistent with the depth used when the PMN test was originally calibrated in the U.S. Midwest (Bundy \& Meisinger, 1994). Anaerobic potentially mineralizable $\mathrm{N}$ was calculated by determining the extractable $\mathrm{NH}_{4}-\mathrm{N}$ in the soil by $2 \mathrm{M} \mathrm{L}^{-1} \mathrm{KCl}$ before incubation and subtracting it from the extractable $\mathrm{NH}_{4}-\mathrm{N}$ after the soil was incubated for $7 \mathrm{~d}$ at $40{ }^{\circ} \mathrm{C}$ (i.e., $\mathrm{PMN}=\mathrm{NH}_{4}-\mathrm{N}$ after incubation minus $\mathrm{NH}_{4}-\mathrm{N}$ before incubation; Bundy \& Meisinger, 1994; Clark et al., 2019b; Keeney \& Bremner, 1966).

\subsection{Plant sampling and analysis}

Whole aboveground plant samples were collected at R6 by clipping six plants at ground level. Ears were removed and 
TA B L E 1 Ranges and means of corn grain yield calculations, soil parameters, and weather conditions across 49 site-years and grouped by soil texture and growing degree-day (GDD) categories

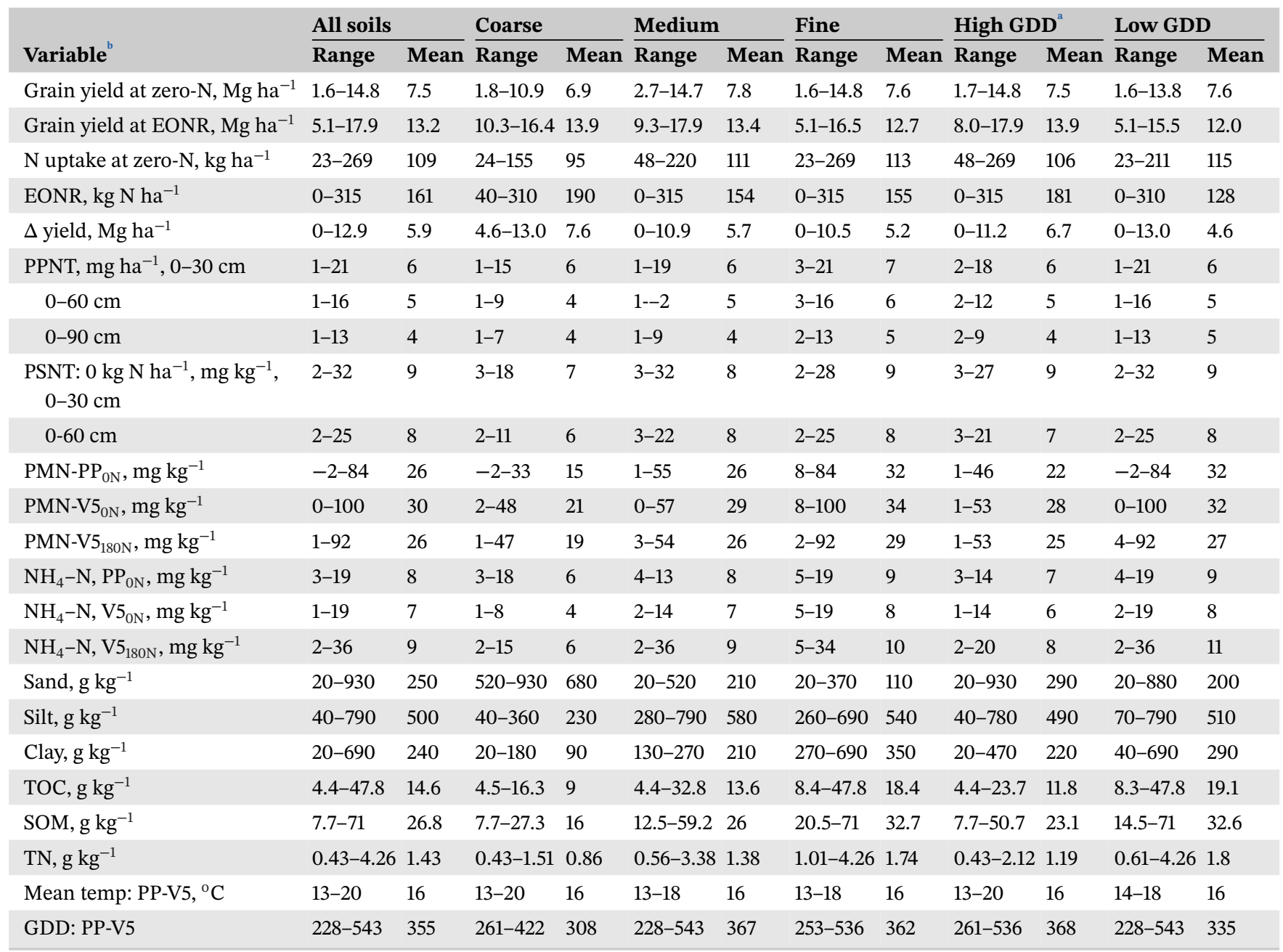

${ }^{a}$ High GDD, sites where Nutrient Star TED GDD units were $\geq 2,222$ (4,000 using $\left.{ }^{\circ} \mathrm{F}\right)$; Low GDD, sites where Nutrient Star TED GDD units were <2,222 (4,000 using $\left.{ }^{\circ} \mathrm{F}\right)$.

${ }^{\mathrm{b}}$ zero-N, $0 \mathrm{~kg} \mathrm{~N}$ ha-1 applied at planting; EONR, economic optimal $\mathrm{N}$ rate; $\Delta$ yield, yield at economic optimal $\mathrm{N}$ rate minus the yield of the control experimental units as determined by the quadratic-plateau model; PPNT, soil $\mathrm{NO}_{3}-\mathrm{N}$ concentration before planting at the 0- to 30-, 0- to 60-, and 0- to 90-cm depth; PSNT, soil $\mathrm{NO}_{3}-\mathrm{N}$ concentration near the $\mathrm{V} 5$ corn development stage where $0 \mathrm{~kg} \mathrm{~N}^{-1}$ was applied at-planting; $\mathrm{PMN}$, anaerobic potentially mineralizable $\mathrm{N} ; \mathrm{PMN}^{\mathrm{P}} \mathrm{PP}_{\mathrm{ON}}$, PMN from soil sampled pre-plant where $0 \mathrm{~kg} \mathrm{~N} \mathrm{ha}^{-1}$ was applied at-planting; PMN-V5 ${ }_{0 \mathrm{~N}}$, PMN from soil sampled at the V5 corn development stage where $0 \mathrm{~kg}$

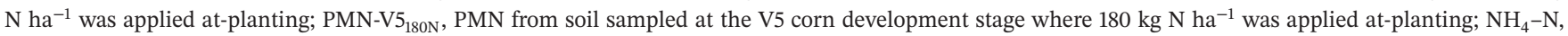
initial $\mathrm{NH}_{4}-\mathrm{N}$ from each of the three PMN samplings $\left(\mathrm{PP}_{0 \mathrm{~N}}, \mathrm{~V}_{0 \mathrm{~N}}\right.$, and $\left.\mathrm{V5}_{180 \mathrm{~N}}\right)$; TOC, total organic $\mathrm{C}$; $\mathrm{TN}$, total $\mathrm{N}$; SOM, soil organic matter; Temp, temperature; PP, pre-plant soil sample timing; V5, 5-leaf stage of corn development.

measured separately from aboveground vegetative matter. Plant materials were dried at $60^{\circ} \mathrm{C}$ until constant mass and weighed to determine dry matter yield. Ears were shelled and grain and cob samples were weighed separately to determine dry matter yield. Plant samples were ground to pass through a 1-mm sieve and $\mathrm{N}$ concentration of the grain and vegetative material was measured using the Dumas combustion method (Bremner, 1996) with an Elementar Rapid N Cube analyzer (Elementar Analysensyteme $\mathrm{GmbH}$, Langenselbold, Germany). Plant $\mathrm{N}$ uptake in the vegetative matter, cob, and grain were determined using their $\mathrm{N}$ concentration and biomass and then summed. Harvest yield was determined by harvesting the middle two rows of each experimental unit and adjusting the moisture to $155 \mathrm{~g} \mathrm{~kg}^{-1}$. The moisture-adjusted weight of the grain collected at R6 from each experimental unit was included in the calculation of final grain yield harvested. Corn grain yield and plant $\mathrm{N}$ uptake at $\mathrm{R} 6$ was converted to $\mathrm{kg} \mathrm{ha}^{-1}$ or $\mathrm{Mg} \mathrm{ha}^{-1}$ as described in Kitchen et al. (2017).

\subsection{Weather}

At each site, daily cumulative rainfall and minimum, maximum, and mean temperatures were calculated from precipitation and temperature data collected every $5 \mathrm{~min}$ from 
a HOBO U30 automatic weather station (Onset Computer Corporation, Bourne, MA). Weather station data was quality checked as described in Kitchen et al. (2017) using Multi-Radar Multi-Sensor precipitation data (The National Severe Storms Lab, NOAA). Mean minimum temperature, mean maximum temperature, mean temperature, and growing degree-days (GDD) were calculated as described in Clark et al. (2019b) for the period from pre-plant soil sampling to the V5 corn development stage.

\section{$2.5 \quad$ Statistical analysis}

Models predicting grain yield and $\mathrm{N}$ uptake at $0 \mathrm{~kg} \mathrm{~N}^{-1}$ (zero-N), grain yield at EONR, and EONR were analyzed in the following ways: all sites combined, soils grouped by texture, and site-years grouped by GDD. Soil types were grouped by texture across all sites into coarse (sandy loam, loamy sand, sandy clay loam, sandy clay, and sand), medium (loam, silt loam, and silt), and fine (clay, silty clay, silty clay loam, and clay loam) categories as described in Tonitto, David, and Drinkwater (2006). The sample size within each texture category included 34 replications with coarse-textured soils, 88 with medium-textured soils, and 74 with fine-textured soils. Sites were grouped by GDD into high- and low-GDD categories using the Nutrient Star TED framework tool (Nutrient Star, 2018; Van Wart et al., 2013). A site-year was considered high GDD when TED GDD units were $\geq 2,222$, and low GDD when TED GDD units were $<2,222$. The sample size within each GDD category included 19 site-years for the low GDD category and 30 siteyears for the high GDD category.

Statistics were performed with SAS software version 9.4 (SAS Institute, Cary, NC). The MEANS procedure was used to determine the range and means of the different explanatory and response variables. The NLIN procedure was used to determine the EONR as described in Kitchen et al. (2017) and Clark et al. (2019a). The grain yield at EONR was calculated using the quadratic plateau model and the EONR. The PROC REG procedure was used to determine the strength of the relationships between corn agronomic variables (grain yield and $\mathrm{N}$ uptake at zero-N, grain yield at EONR, and EONR) and PPNT or PSNT alone and when each of the three PMN values $\left(\mathrm{PP}_{0 \mathrm{~N}}, \mathrm{~V}_{0 \mathrm{~N}}\right.$, and $\left.\mathrm{V} 5_{180 \mathrm{~N}}\right)$ was separately included with and without its initial $\mathrm{NH}_{4}$ $\mathrm{N}$ value $(\alpha=.05)$.

We examined the ability of models with a single predictor variable and more complex models with multiple predictor variables to predict grain yield and $\mathrm{N}$ uptake at zero-N, grain yield at EONR, and EONR. Simple, onevariable models were created by summing the PPNT ( $0-30$, 0-60, or 0-90 cm) or PSNT (0-30 or 0-60 cm) values from different depths with each $\mathrm{PMN}$ value separately $\left(\mathrm{PP}_{0 \mathrm{~N}}\right.$, $\mathrm{V}_{0 \mathrm{~N}}$, or $\mathrm{V}_{180 \mathrm{~N}}$ ) with and without its initial $\mathrm{NH}_{4}-\mathrm{N}$ value included. More complex, multiple-predictor models were created by inputting the PPNT $(0-30,0-60$, or $0-90 \mathrm{~cm})$ or PSNT $(0-30$ or $0-60 \mathrm{~cm})$ values along with the PMN and initial $\mathrm{NH}_{4}-\mathrm{N}$ values as separate predictors in the model. We used the multiple linear regression models because, on average, they predicted corn agronomic variables $16 \%$ better than the simple linear regression models (Supplemental Table S2). Normality and constant variance assumptions were confirmed using residuals within experimental units.

\section{RESULTS AND DISCUSSION}

\subsection{Soil $\mathrm{NO}_{3}-\mathrm{N}$ sampling depth}

Increasing soil sampling depth for the PPNT from $30 \mathrm{~cm}$ to 60 or $90 \mathrm{~cm}$ generally reduced predictability of grain yield and $\mathrm{N}$ uptake at zero- $\mathrm{N}$, grain yield at EONR and EONR (Table 2 Supplemental Tables S3, S4, S5). Table 2 only shows the $R^{2}$ values from regressing plant $\mathrm{N}$ uptake at zero-N against PPNT (0- to 30-, 0 - to 60-, and 0- to 90-cm depths) or PSNT (0- to 30- and 0- to 60-cm depths) alone and when including PMN from each of the three sampling methods separately with and without its initial $\mathrm{NH}_{4}-\mathrm{N}$ value. This was done for simplicity because the change in $R^{2}$ of each corn agronomic variable as soil sampling depth increased was similar, regardless of response variable. The $R^{2}$ values for grain yield at zero-N, grain yield at EONR, and EONR can be found in Supplemental Tables S3, S4, and S5. Pre-plant sampling beyond $30 \mathrm{~cm}$ reduced predictability of corn agronomic variables on fine-textured soils and sites categorized as high GDD by an $R^{2}$ between .10 and .20 , whereas on coarse- and medium-textured soils and sites categorized as low GDD, predictability was minimally altered $\left(R^{2}\right.$ within .09). These results indicate that regardless of soil texture or GDD category, shallow PPNT sampling (0- to $30-\mathrm{cm}$ depth) best predicted grain yield and $\mathrm{N}$ uptake with zero-N, grain yield at EONR, and EONR. Other studies concluded that there was an increase in grain yield or $\mathrm{N}$ response predictability with deeper PPNT soil samples; however, they hypothesized that the increase was likely not sufficient to justify the added cost of obtaining and analyzing the deeper soil samples (Binford, Blackford, \& Cerrato, 1992; Bundy \& Andraski, 1995; Bundy et al., 1999; Cela, Berenguer, Ballesta, Santiveri, \& Lloveras, 2013).

In contrast with PPNT, increasing PSNT sampling depth from 30 to $60 \mathrm{~cm}$ generally increased predictability of plant $\mathrm{N}$ uptake and grain yield at zero- $\mathrm{N}$, grain yield at EONR, and EONR by an $R^{2}$ of .07, on average (Table 2 
TA B L E 2 Model $R^{2}$ from regressing plant $\mathrm{N}$ uptake at $0 \mathrm{~kg} \mathrm{~N} \mathrm{ha}^{-1}$ against soil $\mathrm{NO}_{3}-\mathrm{N}$ from the pre-plant nitrate test (PPNT) or pre-sidedress nitrate test (PSNT) as soil $\mathrm{NO}_{3}-\mathrm{N}$ sampling depth increased alone and when including anaerobic potentially mineralizable $\mathrm{N}$ $(\mathrm{PMN})$ from each of the three sampling methods separately with and without its initial $\mathrm{NH}_{4}-\mathrm{N}$ value across 49 site-years and grouped by soil texture and growing degree-day (GDD) categories. All regressions were significant $(P \leq .05)$ unless otherwise noted

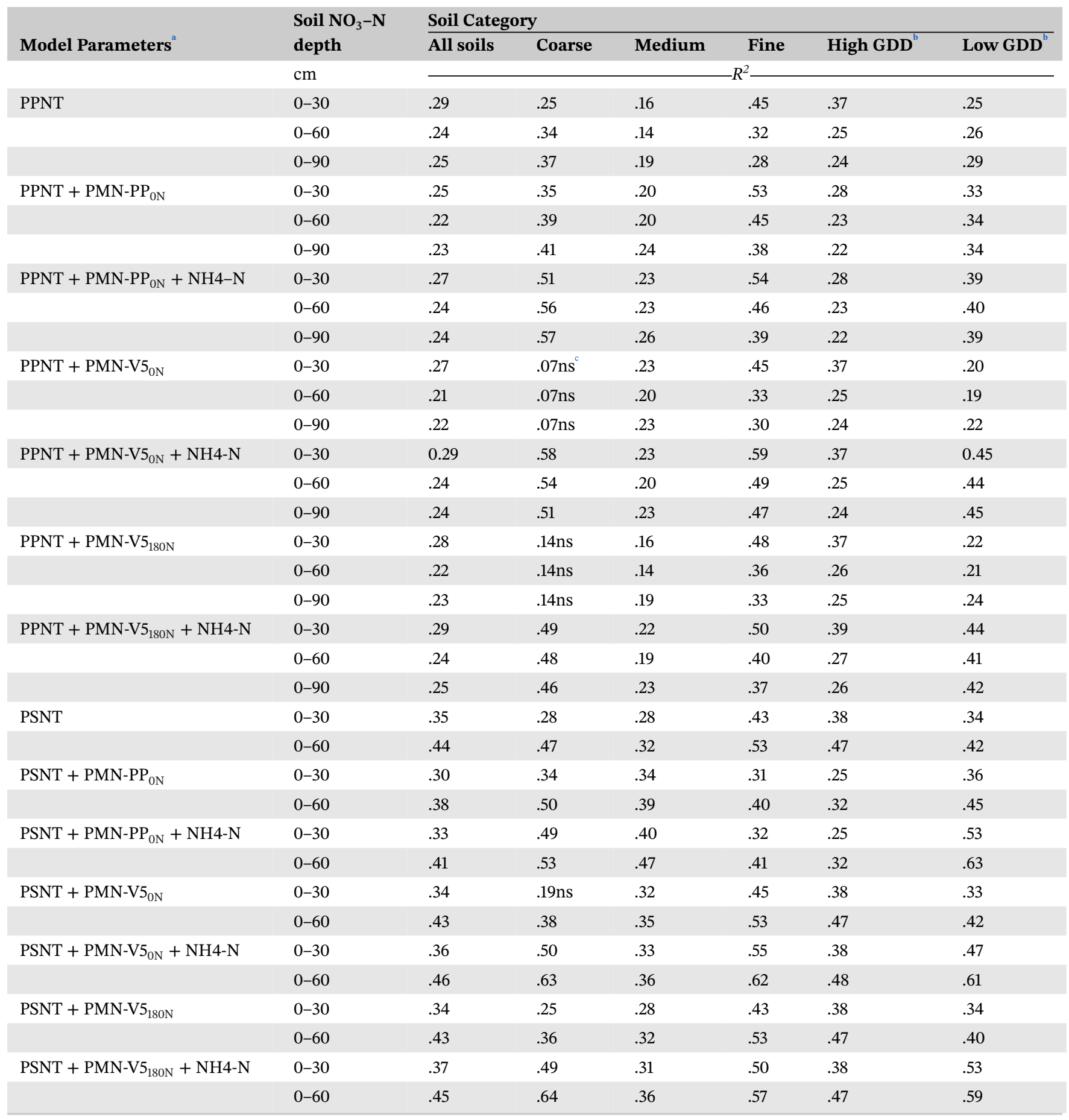

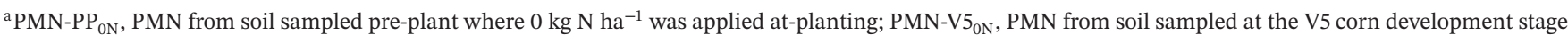

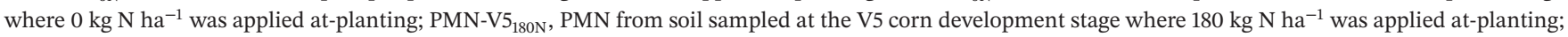
$\mathrm{NH}_{4}-\mathrm{N}$, initial $\mathrm{NH}_{4}-\mathrm{N}$ from each of the three PMN samplings $\left(\mathrm{PP}_{0 \mathrm{~N}}, \mathrm{~V}_{0 \mathrm{~N}}\right.$, and $\left.\mathrm{V}_{180 \mathrm{~N}}\right)$.

${ }^{\mathrm{b}}$ High GDD, sites where Nutrient Star TED GDD units were $\geq 2,222$; Low GDD, sites where the Nutrient Star TED GDD units were $<2,222$.

${ }^{c}$ ns, not significant at the .05 probability level. 
Supplemental Tables S3, S4, S5). Deeper PSNT soil sampling improved predictability of corn agronomic variables more on coarse-textured soils (mean $R^{2}$ improvement of .11) and less on medium- and fine-textured soils and when sites were categorized as low or high GDD (mean $R^{2}$ improvement <.07). Similarly, other studies showed that a deeper PSNT sampling depth improved yield predictability (Binford et al., 1992; Brouder \& Mengel, 2003; Schmitt \& Randall, 1994), especially in soils that had a greater chance of N leaching (Magdoff et al., 1984). These studies support our findings that deeper soil samples on coarse-textured soils, which had greater potential for $\mathrm{N}$ leaching, improved predictions of corn agronomic variables more than on medium- and fine-textured soils. Overall, these results indicate that the deeper $(0-$ to $60-\mathrm{cm})$ PSNT soil sampling best predicted corn agronomic variables, regardless of soil texture or GDD category. We only used the $0-$ to $30-\mathrm{cm}$ depth for the PPNT and 0- to 60-cm depth for the PSNT in the remaining evaluations because these depths resulted in the best predictability of corn agronomic variables and to simplify our discussion. However, results were similar when evaluating the 0 - to $60-$ and $0-$ to $90-\mathrm{cm}$ depths for PPNT and 0- to 30-cm depth for PSNT for each corn agronomic variable (Supplemental tables S3, S4, S5).

\section{2 | Partitioning soils by texture or temperature}

Grouping soils into coarse- medium- and fine-texture categories or into high and low GDD areas compared to evaluating across all sites generally improved the predictability of $\mathrm{N}$ uptake and grain yield at zero- $\mathrm{N}$, grain yield at EONR, and EONR (Tables 3, 4). Across all sites, predicting these corn agronomic variables with PPNT or PSNT models with and without PMN and initial $\mathrm{NH}_{4}-\mathrm{N}$ produced $R^{2}$ values that ranged between $<.01$ and .46 with a mean of .22. Across agronomic variables, partitioning soils by texture categories improved the average $R^{2}$ value by .09 for PPNT or PSNT + PMN + initial $\mathrm{NH}_{4}-\mathrm{N}$ models while partitioning by GDDs improved the average $R^{2}$ value by .07 . Others also reported improved EONR and grain yield predictability when separating soils by yield potential, mineralizable $\mathrm{N}$ potential, and texture (Bundy \& Andraski, 1995; Sainz Rozas et al., 2008; Yost et al., 2013). Thus, regional studies will likely benefit when evaluating soil fertility by areas with similar seasonal air temperatures and soil types compared to combining sites across these categories. Additionally, the predictability of corn agronomic variables was often greater once sites were partitioned by soil texture (mean maximum $R^{2}$ improvement of .27) compared to annual GDD categories (mean maximum $R^{2}$ improvement of .16), indicating that soil texture likely had a greater effect on corn agronomics than annual temperature. These results highlight the need to continue site-specific research based on soil properties and weather to improve corn $\mathrm{N}$ management.

\subsection{Including $\mathbf{P M N}$ and initial $\mathrm{NH}_{4}-\mathrm{N}$ with soil $\mathrm{NO}_{3}-\mathrm{N}$}

Including PMN and initial $\mathrm{NH}_{4}-\mathrm{N}$ with PPNT increased predictability of grain yield and $\mathrm{N}$ uptake at zero- $\mathrm{N}$, grain yield at EONR, and EONR (maximum $R^{2}$ improvement of .33 ; Tables 3,4 ). The only exceptions were predicting grain yield at EONR in medium-textured soils where no relationship existed and predicting EONR in low GDD sites where PPNT alone was best. The inclusion of PMN and initial $\mathrm{NH}_{4}-\mathrm{N}$ with the PPNT $\left(R^{2}=.22-.59\right)$ did not improve grain yield predictability at zero- $\mathrm{N}$ as much as studies in Argentina $\left(R^{2}=.49-.72\right.$; Orcellet et al., 2017; Reussi Calvo et al., 2013). Our lower predictability of grain yield at zero$\mathrm{N}$ may have been due to the lower mean PMN values in this study (PMN: 19-33 mg kg${ }^{-1}$, soil organic matter: 16$32 \mathrm{~g} \mathrm{~kg}^{-1}$; Table 1 compared to those of Orcellet et al. (2017) (PMN: 29-70 mg kg${ }^{-1}$, soil organic matter: $25-60 \mathrm{~g} \mathrm{~kg}^{-1}$ ). The lower values were potentially the result of the lower amount of soil organic matter available for decomposition in our study region. Therefore, the utility of the PPNTbased models with $\mathrm{PMN}$ and initial $\mathrm{NH}_{4}-\mathrm{N}$ to predict grain yield at zero- $\mathrm{N}$ may improve as soil organic matter concentration increases, but further research is needed to confirm this hypothesis.

Including PMN and initial $\mathrm{NH}_{4}-\mathrm{N}$ with PSNT also generally improved predictability of $\mathrm{N}$ uptake and grain yield at zero-N, grain yield at EONR, and EONR (Tables 3, 4). In most soil and GDD categories, the greatest increase in the predictability of agronomic variables came when both PMN and initial $\mathrm{NH}_{4}-\mathrm{N}$ were included with PSNT (maximum $R^{2}$ improvement of .28). When only PMN was included with PSNT, predictability of agronomic variables minimally increased compared to PSNT alone (mean $R^{2}$ improvement of .04). Therefore, $\mathrm{NH}_{4}-\mathrm{N}$ needs to be included with PMN and PSNT to best predict grain yield and $\mathrm{N}$ uptake at zero-N, grain yield at EONR, and EONR. Two exceptions to these results occurred. The first was for predicting grain yield at EONR in medium-textured soils where there was no relationship $(P>.05)$ using any combination of PSNT plus PMN and initial $\mathrm{NH}_{4}-\mathrm{N}$. The second was for predicting EONR in low GDD sites where PSNT alone or including PMN, either with or without initial $\mathrm{NH}_{4}-\mathrm{N}$ predicted EONR similarly $(\leq .04$ increase in $\left.R^{2}\right)$. The predictability of grain yield at zero-N from our study (Table 3 using PSNT $\left(R^{2}=.29-.58\right)$-based models with $\mathrm{PMN}$ and initial $\mathrm{NH}_{4}-\mathrm{N}$ was less than that of Orcellet 
TA B LE 3 Predictability of N uptake and grain yield at $0 \mathrm{~kg} \mathrm{~N} \mathrm{ha}^{-1}$ using the pre-plant nitrate test (PPNT; 0- to 30-cm depth) and pre-sidedress soil nitrate tests (PSNT; 0- to 60-cm depth) alone and combined with anaerobic potentially mineralizable $\mathrm{N}$ (PMN) from one of three sampling methods with and without their initial $\mathrm{NH}_{4}-\mathrm{N}$ value across 49 site-years and grouped by soil texture and growing degree-day (GDD) amount categories. All regressions were significant $(P \leq .05)$ unless otherwise noted

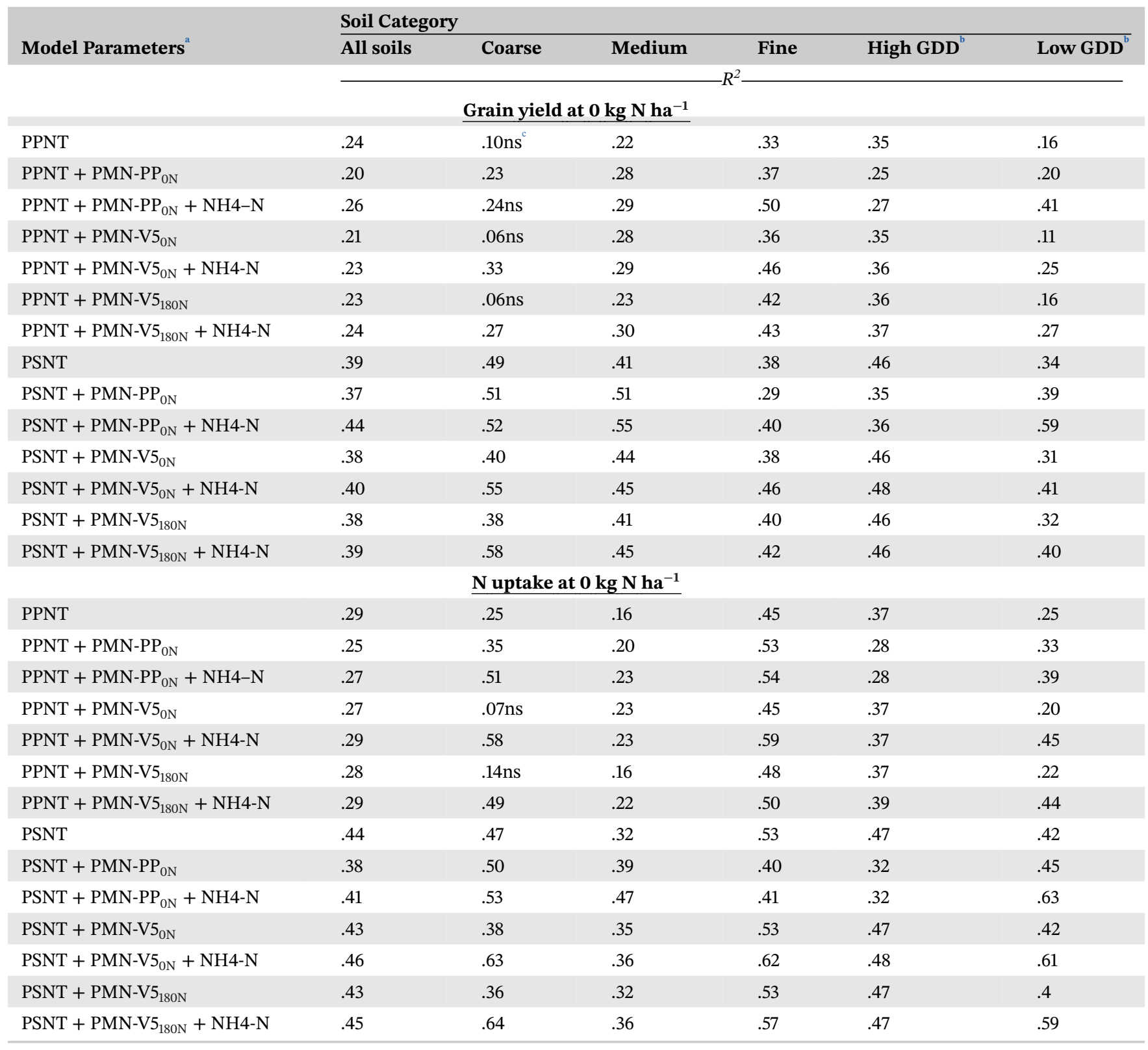

a PMN, anaerobic potentially mineralizable N; $\mathrm{PMN}_{\mathrm{PP}} \mathrm{ON}_{\mathrm{N}}, \mathrm{PMN}$ from soil sampled pre-plant where $0 \mathrm{~kg} \mathrm{~N} \mathrm{ha}^{-1}$ was applied at-planting; PMN-V5 $5_{0 \mathrm{~N}}, \mathrm{PMN}_{\mathrm{N}}$ from soil sampled at the V5 corn development stage where $0 \mathrm{~kg} \mathrm{~N}$ ha $^{-1}$ was applied at-planting; PMN-V5 ${ }_{180 \mathrm{~N}}$, PMN from soil sampled at the V5 corn development stage where $180 \mathrm{~kg} \mathrm{~N} \mathrm{ha}^{-1}$ was applied at-planting; $\mathrm{NH}_{4}-\mathrm{N}$, initial $\mathrm{NH}_{4}-\mathrm{N}$ value from the PMN measurement in the model.

${ }^{\mathrm{b}}$ High GDD, sites where Nutrient Star TED GDD units were $\geq 2,222$ (4,000 using $\left.{ }^{\circ} \mathrm{F}\right)$; Low GDD, sites where the Nutrient Star TED GDD units were <2,222 (4,000 using $\left.{ }^{\circ} \mathrm{F}\right)$.

${ }^{\mathrm{c}} \mathrm{ns}$, not significant at the .05 probability level.

et al. $\left(2017 ; R^{2}=.69-.77\right)$. This lower predictability of grain yield at zero-N with PSNT-based models likely occurred because of lower PMN and PPNT values due to less soil organic matter, as explained earlier.

Compared to PPNT-based models, PSNT-based models better predicted $\mathrm{N}$ uptake and grain yield at zero-N by an $R^{2}$ of .12 on average (Tables 3, 4). Better performance of
PSNT-based models was attributed to accounting for the gains and losses of inorganic $\mathrm{N}$ until the time of rapid $\mathrm{N}$ uptake by the corn crop (Bundy \& Andraski, 1995; Ma \& Wu, 2008; Orcellet et al., 2017; Sainz Rozas, Echeverría, $\&$ Barbieri, 2004). These results indicate that an early season soil-N measurement alone (PPNT) or combined with a mineralizable $\mathrm{N}$ estimate is not as accurate in 
TA B L E 4 Grain yield at the economic optimal N rate (EONR) and EONR predictability using the pre-plant nitrate test (PPNT; 0- to 30-cm depth) and pre-sidedress soil nitrate tests (PSNT; 0- to 60-cm depth) alone and combined with anaerobic potentially mineralizable N (PMN) from one of three sampling methods with and without their initial $\mathrm{NH}_{4}-\mathrm{N}$ value across 49 site-years and grouped by soil texture and growing degree-day (GDD) amount categories. All regressions were significant $(P \leq .05)$ unless otherwise noted

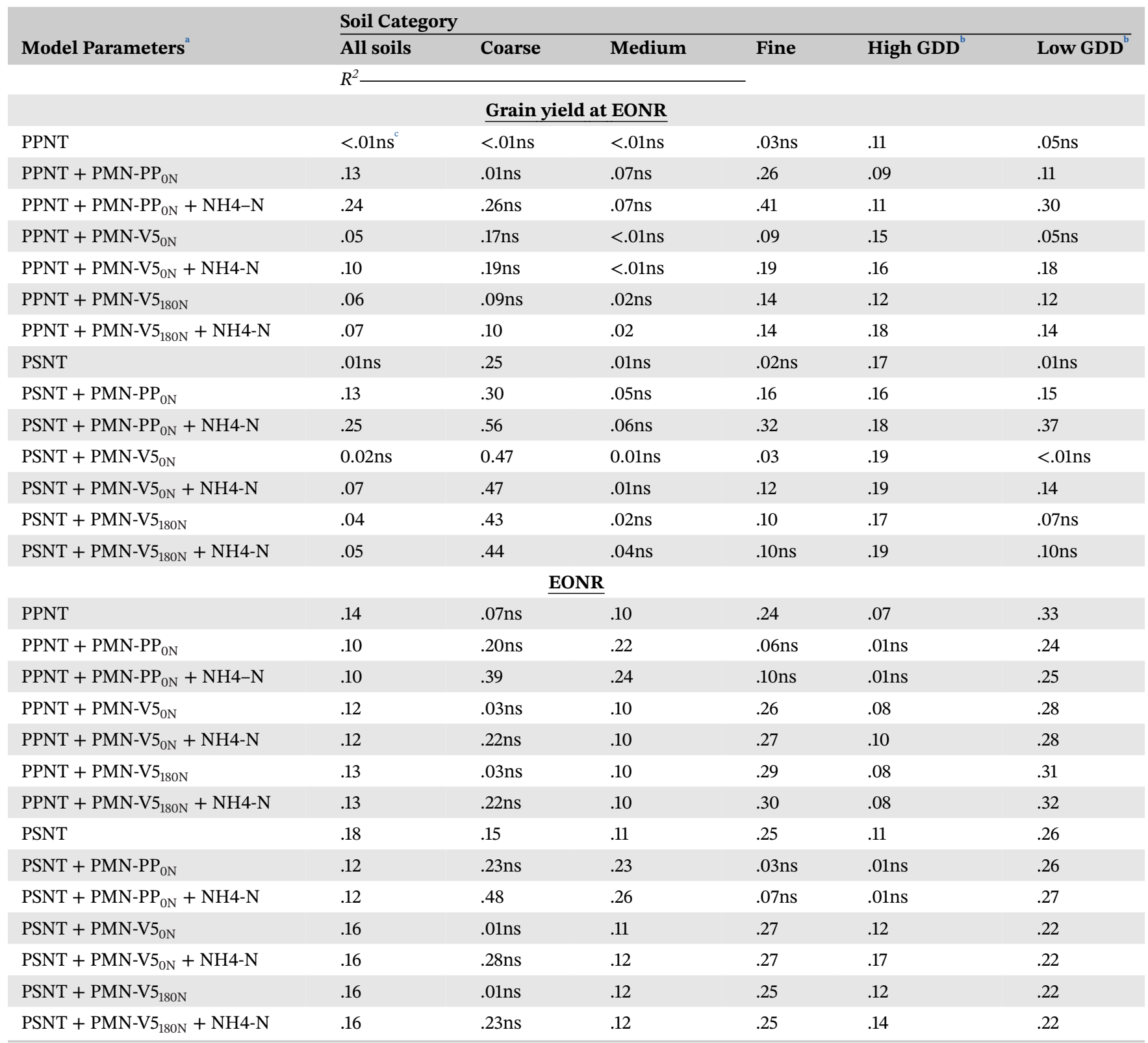

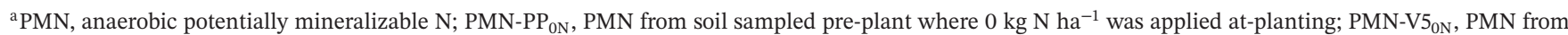
soil sampled at the V5 corn development stage where $0 \mathrm{~kg} \mathrm{~N}$ ha $^{-1}$ was applied at-planting; PMN-V5 ${ }_{180 \mathrm{~N}}$, PMN from soil sampled at the V5 corn development stage where $180 \mathrm{~kg} \mathrm{~N}^{-1}$ was applied at-planting; $\mathrm{NH}_{4}-\mathrm{N}$, initial $\mathrm{NH}_{4}-\mathrm{N}$ value from the $\mathrm{PMN}$ measurement in the model.

${ }^{\mathrm{b}} \mathrm{High}$ GDD, sites where Nutrient Star TED GDD units were $\geq 2,222$ (4,000 using $\left.{ }^{\circ} \mathrm{F}\right)$; Low GDD, sites where the Nutrient Star TED GDD units were <2,222 (4,000 using ${ }^{\circ} \mathrm{F}$ ).

${ }^{\mathrm{c}} \mathrm{ns}$, not significant at the .05 probability level.

predicting grain yield and $\mathrm{N}$ uptake at zero- $\mathrm{N}$ as the PSNT-based models. Conversely, grain yield at EONR and EONR predictability using a PPNT- or PSNT-based model with $\mathrm{PMN}$ and initial $\mathrm{NH}_{4}-\mathrm{N}$ were similar (mean $R^{2}$ difference of .03), indicating either model can be used to predict grain yield at EONR and EONR. The ability to use either the PPNT or PSNT sampling time might provide a logistical benefit because it increases the length of time for soil sample collection and $\mathrm{NO}_{3}-\mathrm{N}$ and PMN analysis. However, the later PSNT sampling time would require a quick turnaround time in the lab to allow growers to apply a sidedress application without high clearance equipment. 


\section{4 | PMN sample timing and $\mathbf{N}$ fertilizer rate}

The PMN sample timing and $\mathrm{N}$ fertilizer rate $\left(\mathrm{PP}_{0 \mathrm{~N}}\right.$, $\mathrm{V}_{0 \mathrm{~N}}$, or $\mathrm{V} 5_{180 \mathrm{~N}}$ ) used in the models that best predicted $\mathrm{N}$ uptake and grain yield at zero-N, grain yield at EONR, and EONR varied by soil texture (Tables 3, 4). For mediumtextured soils, grain yield and $\mathrm{N}$ uptake at zero- $\mathrm{N}$ and EONR predictability were best when $\mathrm{PMN}$ from $\mathrm{PP}_{0 \mathrm{~N}}$ was included. However, for predicting grain yield at EONR, there was no relationship with any combination of PPNT or PSNT plus PMN and initial $\mathrm{NH}_{4}-\mathrm{N}$. For coarse- and fine-textured soils, grain yield at zero-N predictability was similar regardless of the PMN sampling included in the model ( $\leq .06$ increase in $R^{2}$ ). Conversely, including PMN from $\mathrm{V}_{0 \mathrm{~N}}$ or $\mathrm{V}_{180 \mathrm{~N}}$ in the model best predicted $\mathrm{N}$ uptake at zero- $\mathrm{N}$, and including $\mathrm{PMN}$ from $\mathrm{PP}_{0 \mathrm{~N}}$ in the model best predicted grain yield at EONR. In coarse-textured soils, EONR predictability was best when including PMN from $\mathrm{PP}_{0 \mathrm{~N}}$, whereas for fine-textured soils, it was PMN from $\mathrm{V} 5_{0 \mathrm{~N}}$ or $\mathrm{V} 5_{180 \mathrm{~N}}$. Including a PMN value in the model different from the best PMN sampling indicated above reduced predictability of corn agronomic variables by an $R^{2}$ between .09 and .25 . These results indicate that for medium-textured soils, PMN soil sampling should be completed before planting. For coarse- and fine-textured soils, the best PMN sampling time varied by the agronomic variable. Generally, when measuring the potential of a soil to provide $\mathrm{N}$ to a crop (i.e., grain yield and $\mathrm{N}$ uptake at zero-N), PMN from a V5 $5_{0 \mathrm{~N}}$ or $\mathrm{V} 5_{180 \mathrm{~N}}$ sampling should be used, and when determining EONR or grain yield at EONR, PMN from $\mathrm{PP}_{0 \mathrm{~N}}$ should be used.

The PMN sample timing and $\mathrm{N}$ fertilizer rate used $\left(\mathrm{PP}_{0 \mathrm{~N}}, \mathrm{~V}_{0 \mathrm{~N}}\right.$, or $\left.\mathrm{V}_{180 \mathrm{~N}}\right)$ in the models that best predicted $\mathrm{N}$ uptake and grain yield at zero-N, grain yield at EONR, and EONR also varied by GDD category (Tables 3,4). For high GDD sites, $\mathrm{N}$ uptake and grain yield at zero-N and EONR predictability was best when PMN from $\mathrm{V} 5_{0 \mathrm{~N}}$ or $\mathrm{V}_{180 \mathrm{~N}}$ was included, whereas grain yield at EONR was similarly predicted regardless of the PMN sampling included $\left(<.03\right.$ change in $R^{2}$ ). For low GDD sites, $\mathrm{N}$ uptake at zero-N was similarly predicted regardless of the PMN sampling included $\left(<.04\right.$ change in $R^{2}$ ), whereas grain yield at zero-N and grain yield at EONR predictability was best when $\mathrm{PMN}$ from $\mathrm{PP}_{0 \mathrm{~N}}$ was included. Including a PMN value in the model different from the best PMN sampling indicated above reduced predictability of corn agronomic variables by an $R^{2}$ between .10 and .27 . Additionally, for predicting EONR in low GDD sites, PPNT alone performed the best, and including any PMN value reduced EONR predictability by an $R^{2}$ between .01 and .08. These results indicate that PMN sampling should be completed before planting for sites with lower annual
GDDs, but PMN sampling should be delayed to V5 for sites with greater annual GDDs. The influence of annual and seasonal temperatures on the strength of grain yield predictability by PSNT regardless of PMN inclusion has also been reported previously (Andraski \& Bundy, 2002; Orcellet et al., 2017; Sainz Rozas et al., 2008).

Evaluating soils by texture or GDDs and including PMN and initial $\mathrm{NH}_{4}-\mathrm{N}$ with PPNT or PSNT generally improved prediction of $\mathrm{N}$ uptake and grain yield at zero- $\mathrm{N}$, grain yield at EONR, and EONR (Tables 3, 4). Soil $\mathrm{NO}_{3}-\mathrm{N}, \mathrm{PMN}$, and initial $\mathrm{NH}_{4}-\mathrm{N}$ models better predicted the capacity of the soil to provide $\mathrm{N}$ to the crop as measured by $\mathrm{N}$ uptake (mean $R^{2}=.51$ ) and grain yield at zero-N (mean $R^{2}=.47$ ) than predicting EONR (mean $R^{2}=.21$ ) and grain yield at EONR (mean $R^{2}=.22$ ). The lower predictability of grain yield at EONR and EONR were likely due to the variable effect that $\mathrm{N}$ fertilization has on $\mathrm{N}$ mineralization, depending on soil and weather conditions (Clark et al., 2019b; Fernández et al., 2017; Kuzyakova et al., 2006; Ma et al., 1999). The strength of these models, even after the improvements, was still marginal $\left(R^{2}=.09-.64\right.$; mean $\left.R^{2}=.35\right)$, indicating that they alone were insufficient to reliably predict agronomic variables, especially once $\mathrm{N}$ fertilizer was applied. Low predictability of grain yield at EONR and EONR using soil $\mathrm{NO}_{3}-\mathrm{N}, \mathrm{NH}_{4}-\mathrm{N}$, and PMN individually or combined also occurred in other studies $\left(R^{2} \leq .33\right.$; Fox, Roth, Iversen, \& Piekielek, 1989; Nyiraneza et al., 2010; Williams et al., 2007). However, these soil $\mathrm{NO}_{3}-\mathrm{N}$ tests have been successfully used to detect the need for $\mathrm{N}$ fertilization but not the rate (Bast, Mullen, Eckert, \& Thomison, 2012).

\section{4 | CONCLUSIONS}

Soil $\mathrm{NO}_{3}-\mathrm{N}$ sampling should normally be delayed to near the rapid $\mathrm{N}$ uptake stage of corn development (PSNT) to best predict grain yield, $\mathrm{N}$ uptake, and EONR, regardless of soil category. Including initial $\mathrm{NH}_{4}-\mathrm{N}$ and PMN with the PPNT or PSNT can be used to improve grain yield, $\mathrm{N}$ uptake, and EONR predictions. However, even with the improvements in predictions of corn agronomic measurements with these variables or partitioning soils by other variables such as texture or GDD, the overall predictability of grain yield, $\mathrm{N}$ uptake, and EONR was marginal $\left(R^{2}=.09-.64\right.$; mean $\left.R^{2}=.35\right)$. Therefore, including PMN with PPNT or PSNT is not suggested as a tool to improve N fertilizer management in the U.S. Midwest.

\section{ACKNOWLEDGEMENTS}

We would like to thank DuPont Pioneer for funding this research. The authors thank the supporting scientists (Matt Yost; Dan Barker, IA; Lakesh Sharma, Amitava 
Chatterjee, and Norm Cattanach, ND; Todd Andraski, WI; and Tim Hart, DuPont Pioneer), graduate students (Curtis Ransom and Gregory Bean, MO; Christopher Bandura, WI; and Matt Shafer, IN), field technicians (Matt Volkmann, MO; Jason Niekamp and Joshua Vonk, IL; Glen Slater, NE; Andrew Scobbie, Thor Sellie, Nicholas Severson, Darby Martin, and Erik Joerres, MN), and cooperating farmers and research farm personnel for their help in completing this project. Mention of trade names or commercial products in this publication is solely for the purpose of providing information and does not imply recommendation or endorsement by the affiliated universities or the U.S. Department of Agriculture.

\section{O R C I D}

Jason D. Clark (1) https://orcid.org/0000-0001-7793-6411 Kristen S. Veum (10 https://orcid.org/0000-0002-6492-913X James J. Camberato (1) https://orcid.org/0000-0002-6677$854 \mathrm{X}$

David W. Franzen (10 https://orcid.org/0000-0003-48628086

Daniel E. Kaiser (10 https://orcid.org/0000-0002-8478-701X Newell R. Kitchen (1) https://orcid.org/0000-0003-2268-

9016

Emerson D. Nafziger (1) https://orcid.org/0000-0002-65781624

\section{RE F E R E N C ES}

Abendroth, L. J., Elmore, R. W., Boyer, M. J., \& Marlay, S. K. (2011). Corn growth and development (Iowa State University Extension PMR 1009). Ames, IA: Iowa State University.

Andraski, T. W., \& Bundy, L. G. (2002). Using the presidedress soil nitrate test and organic nitrogen crediting to improve corn nitrogen recommendations. Agronomy Journal, 94, 1411-1418. https:// doi.org/10.2134/agronj2002.1411

Barbieri, P. A., Echeverría, H. E., \& Saínz Rozas, H. R. (2008). Presidedress soil nitrogen test for no-tillage maize at different row spacing. Agronomy Journal, 100, 1101-1105. https://doi.org/10. 2134/agronj2007.0130.

Bast, L. E., Mullen, R. W., Eckert, D. J., \& Thomison, P. R. (2012). Evaluation of the pre-sidedress soil nitrate test in Ohio. Crop Management, 11, 1-8. https://doi.org/10.1094/CM-2012-0409-01-RS

Binford, G. D., Blackmer, A. M., \& Cerrato, M. E. (1992). Relationships between corn yields and soil nitrate in late spring. Agronomy Journal, 84, 53-59. https://doi.org/10.2134/agronj1992. $00021962008400010012 \mathrm{x}$

Bremner, J. M. (1996). Nitrogen-total. In D. L. Sparks (Ed.), Methods of soil analysis. Part 3: Chemical methods. (pp.1085-1122). Madison, WI: ASA, CSSA, and SSSA.

Broadbent, F. E., \& Hauck, R. D. (1984). Plant use of soil nitrogen. In R. D. Haulk (Ed.), Nitrogen in crop production (pp. 171-182). Madison, WI: ASA, CSSA, and SSSA.

Brouder, S. M., \& Mengel, D. B. (2003). The presideress soil nitrate test for improving $\mathrm{N}$ management in corn (Purdue University Cooperative Extension Services AY-314-2). Purdue, IN: Purdue University.
Bundy, L. G., \& Andraski, T. W. (1995). Soil yield potential effects on performance of soil nitrate tests. Journal of Production Agriculture, 8, 561-568. https://doi.org/10.2134/jpa1995.0561.

Bundy, L. G., \& Meisinger, J. J. (1994). Nitrogen availability indices. In R. W. Weaver (Ed.), Methods of soil analysis: Biochemical and microbial properties (pp. 951-984). SSSA Monograph 5. Madison, WI: SSSA.

Bundy, L. G., Walters, D. T., \& Olness, A. E. (1999). Evaluation of soil nitrate tests for predicting corn nitrogen response in the North Central Region (Wisconsin Agricultural Experiment Station Publication No. 342). Madison, WI: University of Wisconsin-Madison.

Cela, S., Berenguer, P., Ballesta, A., Santiveri, F., \& Lloveras, J. (2013). Prediction of relative corn yield with soil-nitrate tests under irrigated Mediterranean conditions. Agronomy Journal, 105, 11011106. https://doi.org/10.2134/agronj2012.0473.

Clark, J. D., Fernández, F. G., Veum, K. S., Camberato, J. J., Carter, P. R., Ferguson, R. B., ... Shanahan, J. F. (2019a). Predicting economic optimal nitrogen rate with the anaerobic potentially mineralizable nitrogen test. Agronomy Journal, 5, 1-10. https://doi.org/ 10.2134/agronj2019.03.0224.

Clark, J. D., Veum, K. S., Fernández, F. G., Camberato, J. J., Carter, P. R., Ferguson, R. B., ... Shanahan, J. F. (2019b). United States Midwest soil and weather conditions influence anaerobic potentially mineralizable nitrogen. Soil Science Society of America Journal, 83, 1137-1147. https://doi.org/10.2136/sssaj2019.02.0047.

Clark, J. D., Veum, K. S., Fernández, F. G., Kitchen, N. R., Camberato, J. J., Carter, P. R., ... Shanahan, J. F. (2020). Soil sample timing, nitrogen fertilization, and incubation length influence anaerobic potentially mineralizable nitrogen. Soil Science Society of America Journal, 84, 1-11. https://doi.org/10.1002/saj2.20050.

Culman, S. W., Snapp, S. S., Green, J. M., \& Gentry, L. E. (2013). Shortand long-term labile soil carbon and nitrogen dynamics reflect management and predict corn agronomic performance. Agronomy Journal, 105, 493-502. https://doi.org/10.2134/agronj2012.0382.

Fernández, F. G., Fabrizzi, K. P., \& Naeve, S. L. (2017). Corn and soybean's season-long in-situ nitrogen mineralization in drained and undrained soils. Nutrient Cycling in Agroecosystems, 107, 3347. https://doi.org/10.1007/s10705-016-9810-1.

Fox, R. H., Roth, G. W., Iversen, K. V., \& Piekielek, W. P. (1989). Soil and tissue nitrate tests compared for predicting soil nitrogen availability to corn. Agronomy Journal, 81, 971-974. https://doi.org/10. 2134/agronj1989.00021962008100060025x.

Gelderman, R. H., \& Beegle, D. (2015). Nitrate-nitrogen. In M. Nathan \& R. Gelderman (Eds.), Recommended chemical soil test procedures for the North Central Region (pp. 5.1-5.4). Columbia, MO: University of Missouri.

Keeney, D. R., \& Bremner, J. M. (1966). Comparison and evaluation of laboratory methods of obtaining an index of soil nitrogen availability. Agronomy Journal, 58, 498-503. https://doi.org/ 10.2134/agronj1966.00021962005800050013x.

Khan, S. A., Mulvaney, R. L., \& Hoeft, R. G. (2001). A simple soil test for detecting sites that are nonresponsive to nitrogen fertilization. Soil Science Society of America Journal, 65, 1751-1760. https://doi. org/10.2136/sssaj2001.1751.

Kitchen, N. R., Shanahan, J. F., Ransom, C. J., Bandura, C. J., Bean, G. M., Camberato, J. J., ... Shafer, M. (2017). A public-industry partnership for enhancing corn nitrogen research and datasets: Project description, methodology, and outcomes. Agronomy Journal, 109, 2371-2388. https://doi.org/10.2134/agronj2017.04.0207. 
Kuo, S., Sainju, U. M., \& Jellum, E. (1996). Winter cover cropping influence on nitrogen mineralization, presidedress soil nitrate test, and corn yields. Biology and Fertility of Soils, 22, 310-317. https://doi.org/10.1007/BF00334575.

Kuzyakova, I. F., Turyabahika, F. R., \& Stahr, K. (2006). Time series analysis and mixed models for studying the dynamics of net $\mathrm{N}$ mineralization in a soil catena at Gondelsheim (S-W Germany). Geoderma, 136, 803-818. https://doi.org/10.1016/j.geoderma.2006. 06.003.

Ma, B. L., Dwyer, L. M., \& Gregorich, E. G. (1999). Soil nitrogen amendment effect on seasonal nitrogen mineralization and nitrogen cycling in maize production. Agronomy Journal, 91, 10031009. https://doi.org/10.2134/agronj1999.9161003x.

Ma, B. L., \& Wu, T. Y. (2008). Plant-available nitrogen in the soil: Relationships between pre-plant and pre-sidedress nitrate tests for corn production. Journal of Plant Nutrition and Soil Science, 171, 458465. https://doi.org/10.1002/jpln.200700091.

Magdoff, F. (1991). Understanding the Magdoff pre-sidedress nitrate test for corn. Journal of Production Agriculture, 4, 297-305. https://doi.org/10.2134/jpa1991.0297.

Magdoff, F. R., Ross, D., \& Amadon, J. (1984). A soil test for nitrogen availability to corn. Soil Science Society of America Journal, 48, 1301-1304. https://doi.org/10.2136/sssaj1984. 03615995004800060020x.

Mahal, N. K., Castellano, M. J., \& Miguez, F. E. (2018). Conservation agriculture practices increase potentially mineralizable nitrogen: A meta-analysis. Soil Science Society of America Journal, 82, 12701278. https://doi.org/10.2136/sssaj2017.07.0245.

Morris, T. F., Murrell, T. S., Beegle, D. B., Camberato, J. J., Ferguson, R. B., Grove, J., ... Yang, H. (2018). Strengths and limitations of nitrogen rate recommendations for corn and opportunities for improvement. Agronomy Journal, 110, 1-37. https://doi.org/10. 2134/agronj2017.02.0112.

Nutrient Star. (2018). TED framework tool. Nutrient Star. Retrieved from http://nutrientstar.org/ted-framework/

Nyiraneza, J., N’Dayegamiye, A., Chantigny, M. H., \& Laverdière, M. R. (2009). Variations in corn yield and nitrogen uptake in relation to soil attributes and nitrogen availability indices. Soil Science Society of America Journal, 73, 317-327. https://doi.org/10. 2136/sssaj2007.0374.

Nyiraneza, J., N’Dayegamiye, A., Gasser, M. O., Giroux, M., Grenier, M., Landry, C., \& Guertin, S. (2010). Soil and crop parameters related to corn nitrogen response in Eastern Canada. Agronomy Journal, 102, 1478-1490. https://doi.org/10.2134/agronj2009.0458.

Orcellet, J., Reussi Calvo, N. I., Sainz Rozas, H. R., Wyngaard, N., \& Echeverría, H. E. (2017). Anaerobically incubated nitrogen improved nitrogen diagnosis in corn. Agronomy Journal, 109, 291298. https://doi.org/10.2134/agronj2016.02.0115.

Reussi Calvo, N. I., Sainz Rozas, H., Echeverría, H., \& Berardo, A. (2013). Contribution of anaerobically incubated nitrogen to the diagnosis of nitrogen status in spring wheat. Agronomy Journal, 105, 321-328. https://doi.org/10.2134/agronj2012.0287.

Roberts, T., Ross, W., Norman, R., Slaton, N., \& Wilson, C. (2011). Predicting nitrogen fertilizer needs for rice in Arkansas using alkaline hydrolyzable-nitrogen. Soil Science Society of America Journal, 75, 1161-1171. https://doi.org/10.2136/sssaj2010.0145.

Ros, G. H., Temminghoff, E. J. M., \& Hoffland, E. (2011). Nitrogen mineralization: A review and meta-analysis of the predictive value of soil tests. European Journal of Soil Science, 62, 162-173. https://doi.org/10.1111/j.1365-2389.2010.01318.x.
Saha, U. K., Sonon, L., \& Biswas, B. K. (2018). A comparison of diffusion-conductimetric and distillation-titration methods in analyzing ammonium- and nitrate-nitrogen in the $\mathrm{KCl}$-extracts of Georgia soils. Communications in Soil Science and Plant Analysis, 49, 63-75. https://doi.org/10.1080/00103624.2017.1421647.

Sainz Rozas, H., Calvino, P. A., Echeverria, H. E., Barbieri, P. A., \& Redolatti, M. (2008). Contribution of anaerobically mineralized nitrogen to the reliability of planting or presidedress soil nitrogen test in maize. Agronomy Journal, 100, 1020-1025. https://doi.org/ 10.2134/agronj2007.0077.

Sainz Rozas, H. R., Echeverría, H. E., \& Barbieri, P. A. (2004). Nitrogen balance as affected by application time and nitrogen fertilizer rate in irrigated no-tillage maize. Agronomy Journal, 96, 1622-1631. https://doi.org/10.2134/agronj2004.1622.

Schmitt, M. A., \& Randall, G. W. (1994). Developing a soil nitrogen test for improved recommendations for corn. Journal of Production Agriculture, 7, 328-334. https://doi.org/10.2134/jpa1994.0328.

Tonitto, C., David, M. B., \& Drinkwater, L. E. (2006). Replacing bare fallows with cover crops in fertilizer-intensive cropping systems: A meta-analysis of crop yield and N dynamics. Agriculture Ecosystems and Environment, 112, 58-72. https://doi.org/10.1016/j.agee. 2005.07.003.

Van Wart, J., van Bussel, L. G. J., Wolf, J., Licker, R., Grassini, P., Nelson, A., ... Cassman, K. G. (2013). Use of agro-climatic zones to upscale simulated crop yield potential. Field Crops Research, 143, 44-55. https://doi.org/10.1016/j.fcr.2012.11.023.

Williams, J. D., Crozier, C. R., White, J. G., Sripada, R. P., \& Crouse, D. A. (2007). Comparison of soil nitrogen tests for corn fertilizer recommendations in the humid southeastern USA. Soil Science Society of America Journal, 71, 171-180. https://doi.org/10.2136/ sssaj2006.0057.

Yost, M. A., Coulter, J. A., Russelle, M. P., Sheaffer, C. C., \& Kaiser, D. E. (2012). Alfalfa nitrogen credit to first-year corn: Potassium, regrowth, and tillage timing effects. Agronomy Journal, 104, 953962. https://doi.org/10.2134/agronj2011.0384.

Yost, M. A., Russelle, M. P., \& Coulter, J. A. (2013). Nitrogen requirements of first-year corn following alfalfa were not altered by fallapplied manure. Agronomy Journal, 105, 1061-1069. https://doi. org/10.2134/agronj2012.0496.

Zebarth, B. J., Younie, M., Paul, J. W., \& Bittman, S. (2002). Evaluation of leaf chlorophyll index for making fertilizer nitrogen recommendations for silage corn in a high fertility environment. Communications in Soil Science and Plant Analysis, 33, 665-684. https://doi.org/10.1081/CSS-120003058.

\section{SUPPORTING INFORMATION}

Additional supporting information may be found online in the Supporting Information section at the end of the article.

How to cite this article: Clark JD, Fernández FG, Veum KS, et al. Soil-nitrogen, potentially mineralizable-nitrogen, and field condition information marginally improves corn nitrogen management. Agronomy Journal.

2020;112:4332-4343. https://doi.org/10.1002/agj2.20335 